\title{
From the Trenches: A Global Survey of Anti-TIP NGOs and Their Views of U.S. Efforts
}

\section{Andrew Heiss \& Judith G. Kelley}

To cite this article: Andrew Heiss \& Judith G. Kelley (2017): From the Trenches: A Global Survey of Anti-TIP NGOs and Their Views of U.S. Efforts, Journal of Human Trafficking

To link to this article: http://dx.doi.org/10.1080/23322705.2016.1199241

$$
\text { 册 Published online: } 05 \text { Sep } 2017 .
$$

Submit your article to this journal $[\pi$

Q View related articles $₫$

View Crossmark data $\nearrow$ 


\title{
From the Trenches: A Global Survey of Anti-TIP NGOs and Their Views of U.S. Efforts
}

\author{
Andrew Heiss (D) and Judith G. Kelley \\ Sanford School of Public Policy, Duke University, Durham, North Carolina, USA
}

\begin{abstract}
Amid the academic and policy critiques of the United States' 15-year push to eliminate human trafficking, the perspective of the nongovernmental organizations (NGOs) working with anti-trafficking advocacy and services has been largely ignored. This article presents the results of a global survey of nearly 500 anti-trafficking NGOs working in 133 countries and is the first NGO-focused survey of its kind. Based on the results of the survey, we provide an overview of the anti-trafficking NGO sector as a whole, detail the relationship between anti-trafficking NGOs and the United States and account for some of the variation in NGO opinions of U.S. efforts. Notably, we find that NGOs are remarkably satisfied with U.S.-led efforts-despite their acknowledged flaws - and that NGOs believe that American anti-TIP policies are important and, on balance, helpful. These results also provide a warning for the future of the United States' anti-trafficking advocacy, suggesting that the United States avoid politicizing its annual Trafficking in Persons Report.
\end{abstract}

\section{KEYWORDS}

Anti-trafficking efforts; anti-trafficking policy; human trafficking; NGOs; Trafficking in Persons Report

Since the United States launched its global campaign against trafficking in persons (TIP) in 2000, criticism has abounded (Chacon, 2006; Horning, Thomas, Henninger, \& Marcus, 2014; Nathan, 2005; Wooditch, 2011). Critics argue that by conditioning its nonhumanitarian nontrade-related assistance on governments' efforts to fight trafficking, the United States has created a "unilateral" "sanctions regime" that is at odds with international law, ineffective, and that imposes U.S. norms under the guise of international law (Chuang, 2006). Others accuse the United States of furthering disagreements about the relationship between prostitution and trafficking (Lerum, McCurtis, Saunders, \& Wahab, 2012), ${ }^{1}$ while some assert that U.S.-led anti-TIP efforts were created to "promote restrictive policies on reproductive rights and sexuality throughout the world" (Foerster, 2009, p. 153). ${ }^{2}$ Yet others have accused the report's use of the term "modern-day slavery" as too expansive a label that has been used to enable "exploitation creep" to

CONTACT Andrew Heiss, PhD Candidate andrew.heiss@duke.edu 9 Sanford School of Public Policy, Duke University, Durham, NC 27708, USA.

Andrew Heiss is a PhD Candidate, Sanford School of Public Policy, Duke University.

Judith G. Kelley is the Kevin D. Gorter Professor of Public Policy and Political Science, Sanford School of Public Policy, Duke University.

${ }^{1}$ The creators of the Trafficking Victims Protection Act (TVPA) were motivated by efforts to eliminate prostitution and used the legislation to prohibit funding any activity related to prostitution and to exclude organizations that did not renounce prostitution from receiving any assistance. This became part of the Bush administration's global antiprostitution agenda and prohibited many organizations from receiving anti-TIP funding because of their connections to prostitution. These policies were eventually successfully challenged in the U.S. Supreme Court (United States Agency for International Development v. Alliance for Open Society International, 2013).

${ }^{2} \mathrm{~A}$ critical discussion of how the United States has defined trafficking norms compared with the UN protocol can be found in much of the work of Chuang and is also discussed in various congressional research reports (Chuang, 2006, 2014; Gallagher \& Chuang, 2012; Siskin, Wyler, \& Seelke, 2009, pp. 439-440; Wyler, 2013). 
broaden the U.S. sphere of influence. ${ }^{3}$ Others argue that all anti-TIP policies-including both U. S.-based legislation and the Palermo Protocol to Prevent, Suppress and Punish Trafficking in Persons, especially Women and Children-cause "collateral damage" by unintentionally harming victims (Gallagher, 2015). Finally, critics allege that the ratings assigned by the U.S. State Department in its annual Trafficking in Persons Report are politically biased (Garcia, 2006; Wooditch, 2011). For instance, after Congress prohibited the United States from negotiating with countries with a Tier 3 rating (the lowest score in the TIP Report) during negotiations for the Trans-Pacific Partnership (TPP) in 2015, the State Department upgraded Malaysia to the Tier 2 Watch List, the second-lowest score (Rosenberg \& Cochrane, 2015; Szep \& Spetalnick, 2015). The U.S. Government Accountability Office (GAO) has acknowledged some weaknesses, as has the Inspector General's Office (Government Accountability Office, 2006; Office of Inspector General, 2012).

Despite all this criticism, some have recognized the State Department's TIP Report as "the most influential and the most trusted indicator of states' performance vis-à-vis human trafficking" (Zaloznaya \& Hagan, 2012, p. 18) and have credited U.S. policy with reinforcing the core provisions of the Palermo Protocol (Gallagher, 2015). Research has found that the policy has contributed to criminalization of human trafficking worldwide (Kelley, 2016; Kelley \& Simmons, 2015).

This close scrutiny of the United States' campaign against human trafficking is warranted, as it is a policy of considerable scope and reach. Yet, amid all these academic and policy debates, one key perspective has not been heard: nongovernmental organizations (NGOs) that provide anti-TIP advocacy and programming and work with this issue on the ground. What do anti-TIP NGOs think of the United States' 15-year push to eliminate trafficking? What do these NGOs think of their relationship with the United States?

Collaboration with civil society organizations and NGOs has long been part of the United States' strategy for battling human trafficking around the world. The U.S. State Department's TIP report is perhaps the most visible symbol of the relationship between the United States and anti-TIP NGOs. Since the report's inception, the State Department has collaborated with NGOs, using published reports and expert testimony from the organizations working directly with human-trafficking victims. Early reports regularly acknowledged NGOs for their advocacy and assistance with information gathering. In 2004, the State Department added a new regular "TIP Heroes" section to the report to highlight the work of prominent activists. These individuals have since been honored at the annual TIP report releases and have been invited to give speeches about their work, providing them with a public platform to advance their advocacy. In 2015, the State Department gave even more prominence to these activists, partnering with the National Underground Railroad Freedom Center to publish a Web site dedicated to its 100 TIP heroes (National Underground Railroad Freedom Center, 2016).

In addition to providing information and expertise for the TIP reports, NGOs furnish invaluable practical support for anti-TIP efforts as they interact with the victims firsthand, raise awareness in the media, observe weaknesses in domestic anti-TIP policies and work closely with local authorities. Secretary John Kerry noted in 2015 that close and sustained partnership with anti-TIP NGOs is "the only way we're going to succeed in this battle" (Kerry, 2015, para. 5). Given their centrality in the global fight against human trafficking and their close connection to the United States, anti-TIP NGOs are well positioned to assess U.S. trafficking policy.

This article presents the results of a global survey of nearly 500 anti-TIP NGOs working in 133 countries. To our knowledge, this is the first survey of its kind. Not only does the survey cast light on

\footnotetext{
${ }^{3}$ Chuang notes:

This exploitation creep has the compelling goal of widening the anti-trafficking net to capture more forms of exploitation. But close analysis reveals that it is also a technique to protect the hegemony of a particular U.S. anti-trafficking approach-one having broad bipartisan support in U.S. politics - and to fend off competing approaches calling for labor rights and migration policy reforms that are particularly contentious in the U.S. context. Exploitation creep enables the United States to expand its "anti-trafficking" influence over areas once deemed non-trafficked forced labor and to generate, via "slavery" rebranding, heightened moral condemnation and commitment to its cause. (2014, p. 611)

Gallagher (2011) offers an excellent analysis of the TIP reports.
} 
NGO views of the U.S. efforts but it also provides a snapshot of global NGO efforts on the ground. The results show that the global NGO community is remarkably supportive of U.S. efforts despite their acknowledged flaws. Through our analysis, we find that these positive views are not correlated with the reception of U.S. funding - that is, NGOs independently find the United States' anti-TIP policies, programs, and reports useful and encouraging. Our findings show how NGOs use the TIP report, experience the United States' active engagement throughout the world and believe that American antiTIP policies are important and, on balance, helpful.

We begin with a brief overview of the history of the United States' 15-year international fight against human trafficking, with special emphasis on the importance of the State Department's annual TIP Report, foundational to U.S. anti-TIP strategy. After describing the methods that we used to survey the global anti-TIP NGO sector, we present our findings (a) by providing a broad overview of the sector as a whole, (b) by detailing the relationship between anti-TIP NGOs and the United States, and (c) by accounting for some of the variation in NGO opinions of U.S. efforts. We conclude with a brief set of possible implications of our findings for American anti-TIP policy.

\section{The United States and anti-TIP efforts}

On October 18, 2000, the United States Congress passed the Trafficking Victims Protection Act, or TVPA (DeStefano, 2007; Efrat, 2012, Chapter 5). Beyond establishing one of the first comprehensive legal regimes dedicated to combatting human trafficking, the TVPA had striking international dimensions. The legislation authorized the State Department to establish the Office to Monitor and Combat Trafficking in Persons (G/TIP, later renamed J/TIP), charged with

[m] easur[ing] and evaluat[ing] progress of the United States and other countries in the areas of trafficking prevention, protection, and assistance to victims of trafficking, and prosecution and enforcement against traffickers, including the role of public corruption in facilitating trafficking. (United States Government, 2000, Sec 105.d.2)

The TVPA established minimum standards for the elimination of trafficking and charged the TIP Office with ranking countries into ranked tiers, not according to the scope of their trafficking problems but according to their governments' efforts in addressing those problems. Countries meeting these minimum standards were assigned as Tier 1, with Tier 2 reserved for countries that did not yet meet the standards but were making significant efforts to do so, and Tier 3 for countries failing to meet the standards and showing no corresponding effort (United States Government, 2000, Sec. 108). In 2004, the State Department created the Tier 2 Watch List as a designation for countries at risk of falling to Tier 3. The TVPA also allowed the State Department to dispense financial assistance to help countries meet these standards and prohibited any "nonhumanitarian, nontrade-related foreign assistance" to countries making insufficient efforts (United States Government, 2000, sec. 103.7), although this threat of sanctions has rarely been meaningfully implemented.

Since 2001, the State Department's TIP Office has grown from a few staff to over 50 people in 2015 and is headed by a special ambassador-at-large to monitor and combat trafficking in persons. The office works closely with U.S. embassies around the world, which in turn work with governments, intergovernmental organizations, and NGOs. The office also works with other U.S. agencies that work abroad such as the Department of Justice (DOJ) and United States Agency for International Development (USAID).

U.S. embassy officials discuss the annual TIP Report with legislators and policy makers at various levels in each country they work in. Immediately following the release of the report, embassy staff meet with officials to discuss the report's findings and recommendations, and, throughout the year, the embassy discusses these issues with local officials, NGOs, and other stake holders. The frequency of such meetings varies across countries. The embassy also may arrange workshops or training for government officials. Embassies are not alone in their lobbying and advocacy-the TIP Office also 
regularly sends emissaries from the United States, and the ambassador-at-large usually makes several trips a year to multiple countries to reiterate the office's recommendations.

As noted, various actors have criticized the United States' anti-TIP policy for its normative content, its political scope, and its uneven implementation, yet systematic evaluation of the perception of the policy on the ground has so far been lacking. It is unclear whether U.S. policy even registers in the dayto-day lives of activists and policy makers working on human-trafficking issues, or whether U.S. engagement stays behind closed political doors. Do the NGOs in the trenches of anti-TIP warfare know of the U.S. efforts, and, if so, what do they think of them? Do NGOs have a relationship with the United States, and, if so, does this inform their views? In what ways, if any, have NGOs seen U.S. policy in practice and what is their commentary? The rest of this article sets out to answer these questions via a two-step process. We first assemble a database of anti-TIP NGOs and collect data about their activities and backgrounds. We then use a survey to explore these organizations' views of U.S. anti-TIP efforts and conclude by discussing the major findings of the survey.

\section{Data and methods}

From July-December 2014 we surveyed organizations engaged in anti-trafficking initiatives in 133 countries. We identified anti-TIP NGOs by conducting hundreds of Internet searches and using dozens of directories and indexes, listed in Appendix B. These efforts produced a database of 1,103 operating anti-TIP NGOs with valid contact information. We then shared our list with Polaris Project, a large international anti-TIP NGO, and we were primary contributors to their comprehensive Global Modern Slavery Directory (Polaris Project, 2016). Because we were interested in views of the United States' work around the world, we limited our survey to NGOs working outside the United States. Accordingly, our survey misses a sizable segment of the anti-TIP NGO sector. However, it is difficult to determine the exact number of exclusively U.S.-focused NGOs that we omitted, as none of the directories we consulted consistently indicate where these organizations work. As a rough approximation, we estimate that our database omits less than $20 \%$ of the anti-TIP NGOs around the world. ${ }^{4}$

We received responses from 480 unique organizations, yielding a response rate of $43.5 \%$, which far exceeds that of most NGO surveys (Baruch \& Holtom, 2008). Because NGOs often work in multiple countries, we allowed respondents to answer a series of country-specific questions for up to five different countries, resulting in 561 country-organization responses. The majority of respondents (415, or $86.5 \%)$ answered for only one country, while 65 respondents reported on TIP work in two or more countries.

Online surveys pose several methodological challenges. First, small grassroots organizations without an online presence are missing from our database. Second, respondents could face technological or language barriers. As a result, the survey does not represent the entire sector. Finally, all surveys have response bias-willingness to participate is rarely random. Both the geographic distribution (e.g., the proportion of NGOs headquartered in Asia, Africa, etc.) and the range of advocacy issues in which NGOs engage (e.g., the proportion of NGOs working on crime, drugs, children's rights, etc.) are balanced between respondents and nonrespondents and thus did not influence their decision to participate. However, NGOs that had a primary focus in TIP issues were significantly more likely to respond to the survey: $68 \%$ of nonrespondents had a secondary focus on trafficking, in contrast to $47 \%$ of respondents. This indicates that the NGOs that are most involved in trafficking advocacy were more willing to participate in the survey.

We took several steps to address these biases and threats to validity, based on the methods and recommendations of others (Büthe \& Mattli, 2011; Edwards et al., 2009). To encourage participation, we sent each NGO a set of three personalized e-mail invitations, resent approximately every two

\footnotetext{
${ }^{4}$ Two hundred thirty of the 1,103 NGOs (20.1\%) in our list are headquartered in the United States, which is comparable to the 339 U.S.-based organizations in Polaris Project's directory of 1,763 NGOs (19.2\%). However, many of these U.S.-based NGOs work internationally and do not engage in domestic advocacy. We, thus, conservatively overestimate $20 \%$ as the maximum proportion of U.S.-focused NGOs.
} 
weeks. Organizations without a working e-mail address were contacted by phone. Finally, we posted an invitation to participate in the survey in a LinkedIn discussion group used by anti-trafficking NGOs, although this yielded few responses. Each invitation included a link to the survey and an offer to complete the survey via phone. To reduce language barriers, we translated the survey into Spanish and Russian and encouraged respondents to answer all free-response questions in their native language. We provided additional reminders and assistance to respondents who began the survey but did not complete it (often due to technological issues). The vast majority of respondents (463, or 96.5\%) completed the survey online; 14 were completed over the phone and 3 were collected via the LinkedIn invitation.

Finally, to avoid response bias and cueing respondents who might have particular views of the United States, we framed the survey as an effort to better understand the anti-TIP advocacy sector in general. To reinforce this emphasis, we first asked respondents about their organizations in general and their knowledge of TIP issues in the countries in which they work and then asked which actors (embassies, NGOs, international organizations, etc.) had been active in those countries, allowing them to volunteer information about the U.S. embassy without prompting. Only after this did we ask questions specifically about the presence and quality of the United States' anti-TIP work. In 33 instances, respondents did not initially list the United States as an active anti-TIP player in the freeresponse question but later indicated U.S. support and advocacy, which suggests that NGOs did not decide to participate in the survey based on their prior opinions of the United States. Additionally, nearly $90 \%$ percent of respondents completed the survey after beginning it, revealing that NGOs generally did not change their decision to participate once the survey turned to U.S.-focused questions. A statement in our invitations that the principal investigator was a professor at an American university was the only indication that the survey could contain questions related specifically to the United States. However, the invitation emphasized that the purpose of the survey was to help build a complete database of anti-TIP NGOs and to understand their efforts. ${ }^{5}$ As a final measure, we allowed respondents to remain anonymous to reduce any potential fear of repercussion. ${ }^{6}$ Thus, we minimized the likelihood that opinions of the United States and its antiTIP efforts influenced decisions to participate in the survey, thereby reducing response bias.

We merge survey responses with several supplementary data sources in order to compare NGO experiences with more quantitative country-level characteristics. We calculate each country's average TIP rating between 2000-2015, as well as the absolute change in rating from the first year to the most recent year each country was included in the TIP report. ${ }^{7}$ We use data from the 3P Antitrafficking Policy Index to measure each country's progress in improving human anti-trafficking prosecution, protection, and prevention (Cho, 2015). This index is based on independent assessments of the annual TIP report and other sources and measures progress in a host of specific subindicators, ultimately yielding a score between 3-15, with higher numbers indicating better progress (Cho, 2015, 2016). We look at both the official TIP ratings and the $3 \mathrm{P}$ index because the two indicators measure different phenomena. TIP ratings reflect formal U.S. diplomatic pressure and act as a form of scorecard diplomacy (Kelley \& Simmons, 2015), while the 3P index reflects the concrete progress that governments have made in specified policy areas. As with the raw tier ratings, we calculate each country's average TIP policy index and the absolute change between the first and most recent year. Finally, we use the sum of political rights and civil liberties from Freedom House's Freedom in the World index as a proxy for a country's level of democratization (Freedom House, 2016).

We report basic summary statistics and cross-tabulations of survey responses. The statistical findings are solely descriptive and serve to help interpret many of the trends we discovered in the anti-TIP NGO

\footnotetext{
${ }^{5}$ The language of the invitation and the entire survey are available online at https://github.com/andrewheiss/From-the-TrenchesAnti-TIP-NGOs-and-US/blob/master/survey/invitation.md and https://github.com/andrewheiss/From-the-Trenches-Anti-TIPNGOs-and-US/blob/master/survey/survey.md .

${ }^{6}$ Thirty-three percent of respondents opted to remain anonymous.

${ }^{7}$ Coded as 1, 2, and 3 for each tier level and 2.5 for countries on the Watch List.
} 
sector. We use inferential statistics (including $t$ tests, chi-square tests, and one-way analysis of variance [ANOVA]) only to check for differences in means and associations between responses.

In addition to statistical analysis, we rely on interpretive qualitative analysis of NGOs' freeresponse answers $-82 \%$ of respondents chose to answer at least one of the 12 open-ended questions. One of this study's primary contributions is to allow NGOs themselves to speak about their experiences, and, as such, we extensively quote their responses. To maintain anonymity, we removed all potentially identifiable information from all quotes used in this article and reference the sources of each quote with a randomly assigned four-digit ID number. In the interest of preserving full confidentiality, we also anonymized the responses of organizations that explicitly gave their consent to be identified-instead of mixing anonymous and identified sources, all responses are equally anonymous. Finally, to help ensure that quotes from organizations that requested full anonymity cannot be reidentified, we only included organizations that consented to not be anonymous in our collaboration with the Polaris Project's global directory project. Though it is possible that some of our survey's anonymous respondents are independently included in the Global Modern Slavery Directory, we did not contribute their information.

We analyzed the results of our survey to answer three general questions about the anti-TIP NGO sector and its relationship to the United States' anti-TIP efforts:

(1) An overview of the TIP sector: What does the anti-TIP NGO sector look like and what kind of work do individual NGOs do? How knowledgeable are they of their governments' policies and how closely do they work with the government?

(2) Experiences with the United States: How do anti-TIP NGOs experience the extent and character of the United States' anti-trafficking efforts? How do they interact with the United States, if at all?

(3) Views of U.S. policy: How do anti-TIP NGOs assess the United States' efforts and what factors correlate with their opinion?

\section{An overview of the TIP sector}

\section{Where do anti-TIP NGOs work?}

The anti-TIP NGOs we surveyed are spread throughout the world and have a nearly global reach (see Figure 1). As seen in Figure 2, 60\% of NGOs have their headquarters in either Asia or Europe, roughly a quarter are based in North or South America, and fewer than $20 \%$ are based in Africa. NGOs are not limited to advocacy within their own countries-the majority of these organizations work in Asia (especially in trafficking hotspots like India, Nepal, Thailand, and the Philippines), with less work in Europe and the Americas. Though fewer NGOs are based in Africa, a larger proportion of NGOs work there than in the Americas. Organizations based in the Americas, in particular, are more likely to work outside their home regions, although this may be because we excluded U.S. NGOs who worked only in the United States. With this exclusion, only 50\% of American NGOs work in the Americas, 30\% work in Asia, and 12\% in Africa. In contrast, NGOs based elsewhere are much more likely to stay close to home, as $98 \%, 97 \%$, and $83 \%$ of NGOs headquartered in Asia, Africa, and Africa work in their respective regions.

The reasons for these imbalances may be many. NGOs working in poorer countries may fall under the radar of the Internet or lack sufficient English content on their Web site for identification and, thus, were missed in the database. This could account for the low number of Chinese NGOs, for example, although it is also conceivable that the number of such NGOs in China is already relatively low. That said, the regional patterns identified here resemble the findings of previous studies (Foot, Toft, \& Cesare, 2015; Limoncelli, 2016), which show that NGOs and governments in richer countries in the Americas, Asia, and Europe sponsor many more NGOs and that these organizations engage in advocacy overseas as well as at home. 


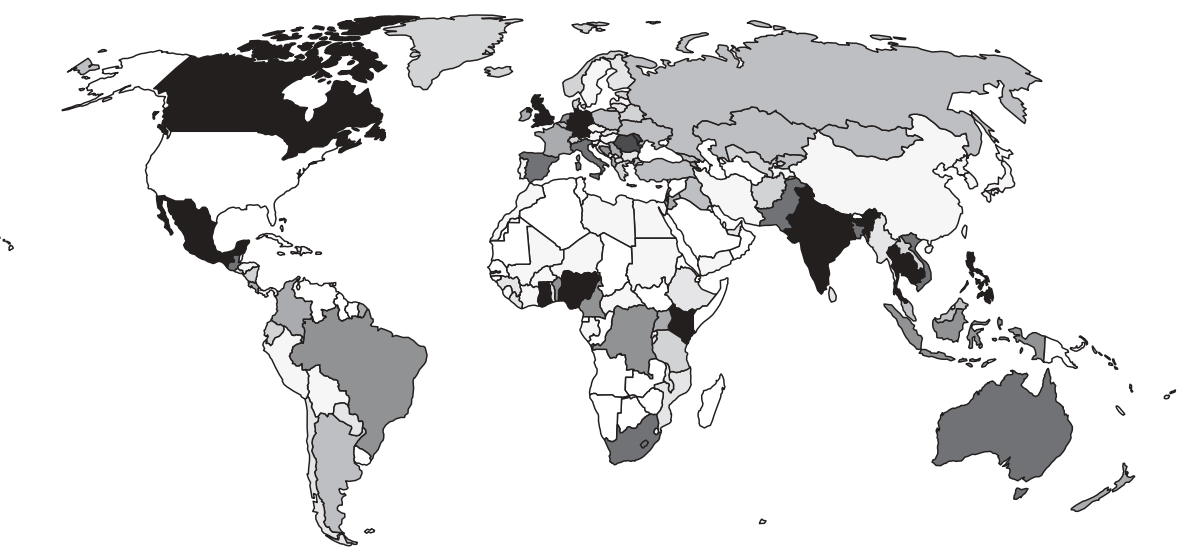

NGOs working in country

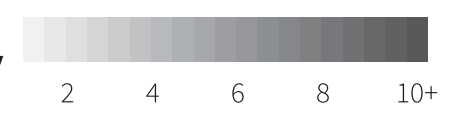

Figure 1. Countries where NGOs work, excluding NGOs working only in the United States.
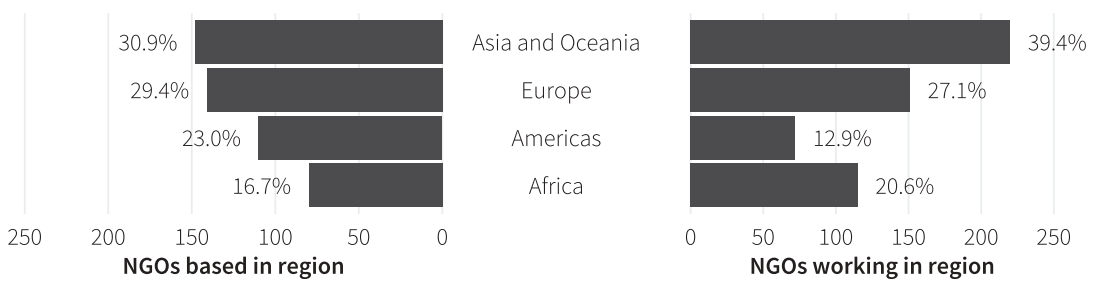

Figure 2. NGO headquarters and target countries, by region, excluding NGOs working only in the United States.

Table 1 displays the answers to basic questions about NGO activities. On average, anti-TIP NGOs spend a little over half of their time and resources focused specifically on fighting trafficking and assisting victims and an overwhelming majority (93\%) has at least some knowledge about the TIP policies in the countries in which they work. Most organizations focus on sex- $(85 \%)$ and labor- $(61 \%)$

Table 1. Summary of Survey Responses Related to Anti-TIP NGO Activities.

\begin{tabular}{|c|c|}
\hline \multicolumn{2}{|l|}{ What do anti-TIP NGOs do? } \\
\hline Question & Summary \\
\hline $\begin{array}{l}\text { Q2.1: About what percent of your organization's time } \\
\text { and resources are spent on fighting against } \\
\text { trafficking or helping victims of trafficking? }\end{array}$ & $\begin{array}{l}\text { Mean: } 56.96 \text {; median: } 56 \text {; standard deviation: } 33.82 \text {; } \\
n=454\end{array}$ \\
\hline $\begin{array}{l}\text { Q3.3: How much does your organization know about } \\
\text { human-trafficking policy in your country? }\end{array}$ & $\begin{array}{l}\text { None }(0.72 \% ; 4) \text {; Very little }(3.06 \% ; 17) \text {; Little }(2.7 \% \text {; } \\
\text { 15); Some }(18.56 \% ; 103) ; \text { A lot }(74.23 \% ; 412) ; \text { Don't } \\
\text { know }(0.72 \% ; 4) ; n=555\end{array}$ \\
\hline $\begin{array}{l}\text { Q2.2: Which human trafficking issues is your } \\
\text { organization most involved with? }\end{array}$ & $\begin{array}{l}\text { Organ trafficking }(6.26 \% ; 30) \text {; Sex trafficking }(85.18 \% \text {; } \\
\text { 408); Labor trafficking (61.38\%; 294); Other (24.22\%; } \\
116) ; n=479\end{array}$ \\
\hline $\begin{array}{l}\text { Q2.3: Which kinds of victims is your organization most } \\
\text { involved with? }\end{array}$ & $\begin{array}{l}\text { Children }(70.08 \% ; 335) ; \text { Adults }(66.53 \% ; 318) ; \text { Other } \\
(15.69 \% ; 75) ; n=478\end{array}$ \\
\hline $\begin{array}{l}\text { Q2.4: Which efforts does your organization focus on } \\
\text { most? }\end{array}$ & $\begin{array}{l}\text { Prevention and education (83.09\%; 398); Prosecutions } \\
\text { and legal issues (39.25\%; 188); Victim protection } \\
(51.77 \% ; 248) ; \text { Victim assistance }(70.98 \% ; 340) ; \text { Other } \\
(26.72 \% ; 128) ; n=479\end{array}$ \\
\hline
\end{tabular}


trafficking issues; $50 \%$ focus on both simultaneously. A handful of organizations (30, or 6\%) work with human-organ trafficking, and dozens of others deal with other issues such as brokered marriages, domestic servitude, illegal adoptions, and forced begging. These findings also reflect previous research, showing that roughly two thirds of anti-trafficking actors address sex and labor issues (Foot et al., 2015).

Approximately two thirds of NGOs serve and advocate for children and/or adult trafficking victims, and many of those who work with adults specified working especially with women and young girls. No type of trafficking issue is more pronounced among different categories of victimsthat is, NGOs are generally equally as likely to help both children and adults with either sex or labor trafficking, suggesting a need for both issues across all ages.

NGOs differ in their strategies to address trafficking. Most organizations (83\%) work on prevention and improved education about TIP issues, and nearly three fourths assist trafficking victims by running safe houses and shelters, operating special hotlines, helping start businesses, or providing physical and emotional health care. Half of NGOs are also involved with other forms of advocacyincluding lobbying and legislative support-and $40 \%$ engage in efforts to prosecute traffickers and to research related legal issues. As with the types of victims, NGO strategies do not differ by the type of trafficking they address-organizations that address either sex or labor trafficking appear to offer roughly the same mix of programming. All in all, the survey shows that NGOs engage comprehensively both with victims and policy advocacy and, in many cases, provide vital services to a wide range of victims.

\section{How do anti-TIP NGOs work with other actors?}

Human trafficking is a complex issue and, accordingly, the anti-TIP NGO sector is quite collaborative. As shown in Table 2, every respondent reported collaborating, partnering, or interacting with other NGOs or civil society organizations, international organizations, foreign embassies, and the national governments of the countries in which they work. Nearly every organization (95\%) sees NGOs and civil society organizations as active in dealing with trafficking issues in their countries, and NGOs regularly form partnerships with religious groups, charities, universities, and community organizations. Around two thirds of NGOs indicated that international organizations such as the International Organization for Migration (IOM), the International Labour Organization (ILO), and the United Nations Office on Drugs and Crime (UNODC) are also active participants in anti-TIP advocacy. Less than half of respondents reported that governments other than the United States are involved in their countries.

Many NGOs also collaborate with the national governments of the countries they work in, as more than half $(53 \%)$ have discussed TIP issues directly with the government. NGOs also see their governments as active-about two thirds of respondents (68\%) say that their local and national

Table 2. Summary of Survey Responses Related to How Anti-TIP NGOs Work with Other Actors.

\begin{tabular}{|c|c|}
\hline Question & Summary \\
\hline $\begin{array}{l}\text { Q3.5: Which of these institutions have been active } \\
\text { in fighting human trafficking in your country } \\
\text { over the last } 10-15 \text { years? }\end{array}$ & $\begin{array}{l}\text { The national government }(67.81 \% ; 375) \text {; NGOs and } \\
\text { civil society }(95.12 \% ; 526) ; \text { Embassies or foreign } \\
\text { governments }(41.95 \% ; 232) ; \text { International } \\
\text { organizations }(66.91 \% ; 370) ; \text { Other }(14.65 \% ; 81) ; \\
n=553\end{array}$ \\
\hline $\begin{array}{l}\text { Q3.20: In your view, how hard is the government of } \\
\text { your country working to combat trafficking in } \\
\text { persons? }\end{array}$ & $\begin{array}{l}\text { Not hard at all }(9.64 \% ; 53) ; \text { Not too hard }(26 \% ; 143) \text {; } \\
\text { Somewhat hard }(40 \% ; 220) \text {; Very hard }(16.91 \% ; 93) ; \\
\text { Extremely hard }(3.45 \% ; 19) \text {; Don't know }(4 \% ; 22) ; \\
n=550\end{array}$ \\
\hline $\begin{array}{l}\text { Q3.26: How have the government's trafficking } \\
\text { efforts in your country changed over the past } \\
10-15 \text { years? }\end{array}$ & $\begin{array}{l}\text { Improved (61.19\%; 339); Remained constant (17.69\%; } \\
98) ; \text { Slowed down (13.72\%; 76); Don't know (7.4\%; } \\
41) ; n=554\end{array}$ \\
\hline
\end{tabular}


governments help combat trafficking, with $61 \%$ reporting that the governments in their target countries work at least "somewhat hard" in working against TIP, and $20 \%$ feel that those governments have worked "very" or "extremely" hard. NGOs largely feel that these efforts have paid off, as more than $60 \%$ of respondents report that their host countries' anti-TIP efforts have improved over the last 10-15 years, and less than 15\% perceive a slowdown in their governments' efforts.

In recent years, NGOs around the world have faced government crackdowns, increased monitoring, and harsher restrictions (Dupuy, Ron, \& Prakash, 2014, 2015; Heiss, 2016a, 2016b). In some instances, these restrictions have occurred in the anti-TIP sector. For example, Uzbekistan has reportedly cracked down on anti-TIP NGOs after they criticized how the government has handled the country's annual cotton harvest (Kelly, 2015). However, overall, anti-TIP NGOs are relatively unencumbered by government regulations, with more than a third of respondents reporting that they feel unrestricted in the countries in which they work. Roughly a quarter of NGOs reported feeling either somewhat or very restricted. Those reporting restrictions represent 66 different countries, which is still a significant share. The restrictions range from strict legal requirements to general government antagonism or apathy toward NGO programming. Several NGOs feel restricted because of tax code limitations on charitable advocacy, similar to the political advocacy limitations the United States imposes on 501(c) (3) charities. ${ }^{8}$ Other organizations experience informal restrictions that hinder advocacy, such as corruption or inefficiency in the police and government bureaucracy. For example, one NGO reported that "we [have] to be certified and continue to submit to monthly reporting, mandatory financial audits, site visits, social welfare approval, government regulations regarding our aftercare property, work permits for all foreign volunteers, annual reporting and additional certifications," ${ }^{9}$ while another noted that "[a]ll work must be approved and done in direct concert with government counterparts. [Our] presence in [the] country [is] controlled and evaluated by government officials, even those who are not familiar with our work." ${ }^{10}$ The burden of complying with uncertain regulations can hamper NGOs and can detract from their work, limiting their ability to protect victims and prosecute offenders. ${ }^{11}$

\section{Experiences with the United States}

As central actors in the fight against human trafficking, over the past 15 years NGOs have observed the United States' anti-TIP efforts throughout the world (see Figure 3). Accordingly, NGOs have a unique perspective of the implementation, effectiveness, and effects of American efforts. The organizations that responded to our survey were quite forthcoming about their experiences with the United States' anti-TIP work. NGOs almost universally identify the United States as a central driving force for TIP advocacy in the countries in which they work. Respondents report that the U.S. State Department's annual TIP report empowers them as they confront and collaborate with national politicians and bureaucrats. NGOs also note that the United States has been particularly effective in its work with local governments, using its TIP reports to pressure governments to implement reforms and then assisting with the practical implementation of new anti-TIP legislation. Finally, NGOs describe the mixed results of the United States' public advocacy. We detail each of these topics in turn.

\section{The centrality of the United States}

While the fight against human trafficking is global in scope and involves the efforts of dozens of actors, NGOs see the United States as by far the most active and influential foreign government. We

\footnotetext{
${ }^{8}$ Responses 1228 and 1265 .

${ }^{9}$ Response 1280 .

${ }^{10}$ Response 1157.

${ }^{11}$ Responses 1016, 1049, 1061, 1118, 1336, 1388, and 1389 among others.
} 


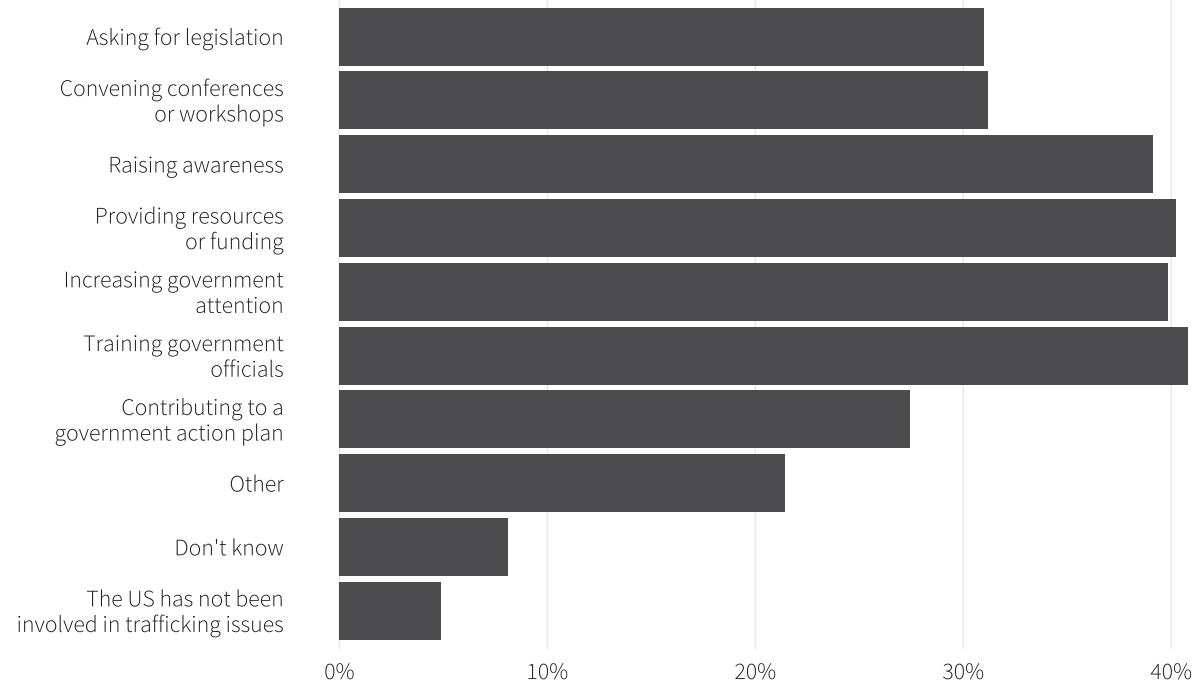

Figure 3. Activities and programming sponsored by the U.S. embassy, as reported by NGOs.

asked respondents to indicate which embassies they knew to be active in anti-TIP work in each of the countries in which they work, and which of those governments were most active. NGOs identified 64 different foreign or regional governments as active, and $77 \%$ of respondents included the U.S. embassy or government in their list (see Figure 4). In fact, the United States was mentioned six times more often (260 mentions) than the next most common country, the United Kingdom (43 mentions). Respondents identified 39 foreign countries as particularly active, and $71 \%$ named the United States as the most active-14 times more often (187 mentions) than the next most foreign actor, the European Union (14 mentions). These questions were entirely unprompted and open ended. When later asked directly about U.S. activities, only 39 NGOs (7.3\%) explicitly reported that the United States had not been involved in any of the countries in which they work.
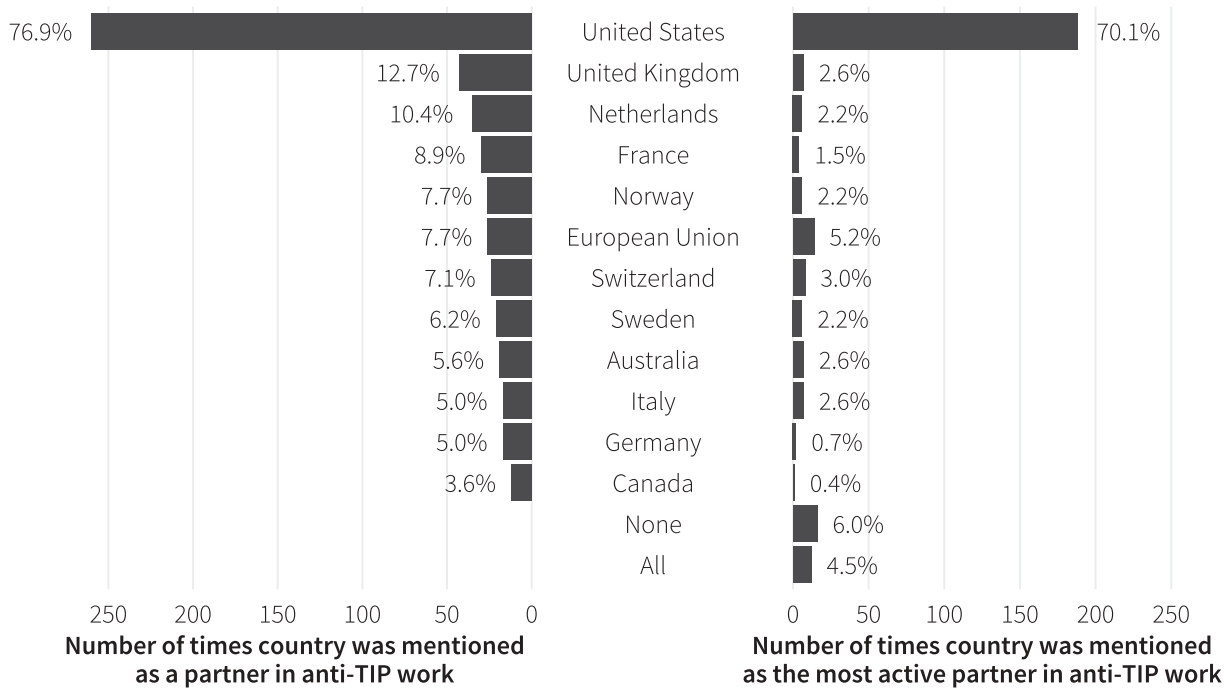

Figure 4. Embassies or foreign governments NGOs reported as active partners in the fight against human trafficking. 
Table 3. Summary of Survey Responses Related to How Anti-TIP NGOs Use the State Department's Annual TIP Report.

\begin{tabular}{|c|c|}
\hline Question & Summary \\
\hline $\begin{array}{l}\text { Q2.5: The U.S. State Department issues an annual } \\
\text { Trafficking in Persons (TIP) report. Have you ever } \\
\text { heard of this annual report? }\end{array}$ & No $(13 \% ; 62) ;$ Yes $(87 \% ; 415) ; n=477$ \\
\hline $\begin{array}{l}\text { Q3.21: Has your organization used the U.S. State } \\
\text { Department's Trafficking in Persons (TIP) report to } \\
\text { discuss trafficking issues with any of these groups? }\end{array}$ & $\begin{array}{l}\text { National government }(52.74 \% ; 212) \text {; Another } \\
\text { government }(16.67 \% ; 67) ; \text { Other NGOs }(77.86 \% ; 313) \text {; } \\
\text { Other }(21.14 \% ; 85) ; n=402\end{array}$ \\
\hline $\begin{array}{l}\text { Q3.22: Which TIP tier rating did your country receive } \\
\text { this year? }\end{array}$ & $\begin{array}{l}\text { Tier } 1(18.79 \% ; 87) \text {; Tier } 2(39.31 \% ; 182) \text {; Watch list } \\
(9.07 \% ; 42) \text {; Tier } 3(9.07 \% \text {; } 42) \text {; Don't know (23.76\%; } \\
110) ; n=463\end{array}$ \\
\hline $\begin{array}{l}\text { Q3.23: Have you ever heard-in public or private- } \\
\text { officials in your country mention the TIP tier rating? }\end{array}$ & No $(56.38 \% ; 265) ;$ Yes $(43.62 \% ; 205) ; n=470$ \\
\hline
\end{tabular}

\section{How NGOs use the TIP report}

From the perspective of anti-TIP NGOs, the TIP report is perhaps the U.S. government's most potent tool for confronting or working with foreign governments. As discussed previously, the TIP report has been criticized for being ineffective and politically motivated. However, for many anti-TIP NGOs, the report is an important resource for advocacy and policy work. Table 3 shows that the overwhelming majority (87\%) of the NGOs surveyed were aware of the report, and, of those organizations that had heard of it, three quarters (76\%) said they knew the rating assigned to the country or countries in which they worked. About half of the NGOs (52\%) use the TIP report to discuss trafficking issues with the governments of the countries in which they work, including individual members of parliament, courts, national and local police forces, and community leaders. ${ }^{12}$ Notably, the majority of respondents (78\%) use the TIP report in their work with other NGOs, indicating its importance within the NGO community. Many organizations reference the report when working with local church groups, schools, trade unions, community centers, youth organizations, and other domestic civil society organizations. ${ }^{13}$ Others cite the report in their own advocacy literature and annual reports. ${ }^{14}$

A minority of respondents was critical, however. Some organizations found it unhelpful and superficial, ${ }^{15}$ that it does not reflect the reality of trafficking issues, ${ }^{16}$ or that it "is so far removed from the truth [that] it appears propagandistic." ${ }^{\prime 17}$ Another NGO found that using the TIP report in their advocacy posed a significant political risk due to anti-American sentiment in the country in which they work. ${ }^{18}$ Echoing some of the criticisms mentioned in the introduction, one NGO reported that the tier rating was politically predetermined and merely reflected "US strategic interests." ${ }^{19}$ Fourteen NGOs explicitly reported that they do not use the TIP report in any of their work with governments or other NGOs.

\section{NGO views of their governments' attitude toward TIP rankings}

As these NGOs advocate and work with governments to improve TIP policy, many have witnessed the effect of the TIP rating on behind-the-scenes politics and policy discussions-a little less than half of respondents $(43 \%)$ indicated that they had heard officials in the countries they work in mention the TIP tier rating. NGOs report that the governments of the countries in which they work

\footnotetext{
${ }^{12}$ Responses 1077, 1165, 1280, 1296, 1343, 1349, and 1473.

${ }^{13}$ Responses 1008, 1144, 1247, 1343, 1371, 1422, 1463, and 1463.

${ }^{14}$ Responses 1190, 1286, 1292, 1325, 1337, 1420, and 1437.

${ }^{15}$ Response 1157.

${ }^{16}$ Responses 1076 and 1079.

${ }^{17}$ Response 1060.

${ }^{18}$ Response 1303.

${ }^{19}$ Response 1037.
} 
tend to mention tier ratings in several contexts. Many government officials showcase their rating to demonstrate or show off their achievements ${ }^{20}$ and to promote their countries as models for fighting and preventing human trafficking. ${ }^{21}$ Some NGOs even report that officials tout their rating "[at] every possible chance." ${ }^{22}$ NGOs report that officials used the TIP ranking to convey shame about their countries' progress and then to redirect this shame to help "initiate, justify and strengthen the activities of the government" ${ }^{\prime 23}$ and to provide additional motivation to pursue anti-TIP policies. Thus, NGOs provided several examples of ways that the TIP report and U.S. support helped improve anti-TIP efforts in the countries in which they work.

That said, some NGOs also reported pushback against the report. They note that some officials expressed frustration-both in public and in private - that the TIP report did not adequately reflect progress. One NGO held a private conversation with an official who was concerned that the poor tier rating made it "it look like [the government] [doesn't] care, but they actually do." ${ }^{24}$ Another noted that government officials often feel that they are rated "unfairly" ${ }^{25}$ or that the rating is "unjustified." ${ }^{26}$ One NGO noted that some local officials blame the United States, claiming that "the placement in such a rating is politically motivated [and] does not reflect the actual work of the state," ${ }^{27}$ and that the tier ratings are simply a general reflection of relations with the United States. Other NGOs report that government officials accuse NGOs-which provide much of the source material for the TIP report-of "making false claims." ${ }^{28}$ In some cases, governments only care about their rating temporarily. One NGO observed that "the government [makes] efforts to close brothels around [the time of the report] to appear as if they are active in this area, but I observed the brothels always opened up again a short time after the report was issued." ${ }^{29}$ Finally, a few NGOs said that governments have used favorable tier rankings as an excuse to stop working on TIP issues, stating that a common government response is that "because [the country] has been ranked tier 1, there is no need to take additional action" or to pursue further anti-TIP legislation. ${ }^{30}$

NGOs feel that the TIP report plays a crucial role in the United States' work in their countries. More than $40 \%$ of NGOs indicated that the United States has increased government attention to TIP issues in the countries in which they work, and the majority of these organizations specifically noted that the U.S. embassy had used the TIP report to do so. Many see the report as the United States' primary means for working directly with foreign governments, noting that the report has been an "extremely important,"31 "very effective," 32 and a "quite useful"33 tool that allows the U.S. government to "[suggest] changes to anti-trafficking laws and policy, [to raise] awareness about trafficking, and [to increase] [foreign government] attention to trafficking. ${ }^{34}$ NGOs also observe that U.S. officials use the report to threaten, to pressure, and to embarrass offending governments, ${ }^{35}$ with officials sometimes "threaten[ing] to cut off grants," ${ }^{36}$ and that the report "force[s] an official response from the government ... every year when it is released." 37 Several NGOs are aware that

\footnotetext{
${ }^{20}$ Responses 1090 and 1377.

${ }^{21}$ Response 1246.

${ }^{22}$ Response 1442.

${ }^{23}$ Response 1497.

${ }^{24}$ Response 1255.

${ }^{25}$ Response 1077.

${ }^{26}$ Response 1457.

${ }^{27}$ Response 1396, translated from original language.

${ }^{28}$ Response 1029.

${ }^{29}$ Response 1378.

${ }^{30}$ Response 1387.

${ }^{31}$ Response 1475.

${ }^{32}$ Response 1442.

${ }^{33}$ Response 1390 .

${ }^{34}$ Response 1158.

${ }^{35}$ Responses 1017, 1158, and 1259.

${ }^{36}$ Response 1335.

${ }^{37}$ Response 1387.
} 
embassies invite high-ranking government officials and party leaders for formal discussions about the report's recommendations and future steps. ${ }^{38}$

\section{Effects of the United States' efforts on national governments}

Anti-TIP NGOs also observe that the United States pushes for policy changes in their countries. About a third of respondents (31\%) report that State Department or embassy staff have explicitly lobbied for anti-TIP legislation. ${ }^{39}$ One organization observed that each time the U.S. ambassador meets with government officials, he reminds them of the need to finalize national legislation and to adhere to UN Security Council resolutions related to trafficking and women's rights. ${ }^{40}$ In several countries, NGOs state that the United States encouraged and lobbied presidents, prime ministers, and legislators to adopt a wide range of laws mandating increased monitoring through regular data collection and inspections and improved prosecutions under stricter criminal statutes, tighter border controls, and travel restrictions. ${ }^{41}$ Two NGOs made special note of formal visits between their countries' respective presidents and then-Secretary of State Hillary Clinton where she explicitly encouraged and lobbied for anti-TIP regulations. ${ }^{42}$

Contrary to some criticisms, not all NGOs feel that U.S. efforts are narrowly focused on legislation without concern for implementation. Beyond lobbying for the passage of legislation, NGOs report that the United States also has helped governments develop practical TIP action plans (27\%). After legislation is passed, NGOs observe American involvement and support in the implementation of new TIP-related policies. In many cases, the United States meets with government officials to show examples of action plans implemented in peer countries and to provide other technical assistance and policy guidance. ${ }^{43}$ Additionally, NGOs note that embassy officials help form intergovernmental task forces and interministerial steering groups to coordinate anti-TIP efforts among various branches of government, as well as to organize national trafficking coalitions to integrate government and civil society strategies and programs. ${ }^{44}$ In at least one country, American staff from the U.S. Department of Justice and USAID formally serve as members of the secretariat for the national TIP commission. ${ }^{45}$

NGOs also report considerable U.S. efforts to train those who oversee and implement these national policies, with $21 \%$ noting that the embassy had trained these officials. The State Department works with the Federal Bureau of Investigations and the Department of Homeland Security to provide specialized training - both in country and in the United States-for foreign law-enforcement officers, military personnel, intelligence agents, and countertrafficking unit staff. ${ }^{46}$ Embassies also partner with the Department of Justice to organize training to orient judges and prosecutors about the new national legislation and to assist with its practical legal implementation. ${ }^{47}$

\section{Views of the United States' public advocacy}

The State Department's TIP Office (J/TIP) funds dozens of public awareness programs around the world. It is difficult to assess the effectiveness of these programs, but one indicator is whether NGOs know about them. Based on our survey results, many NGOs are aware of these on-the-ground efforts. Approximately

\footnotetext{
${ }^{38}$ Responses 1104,1259 , and 1360 .

${ }^{39}$ Note this is consistent with the findings of (Kelley \& Simmons, 2015) that U.S. anti-TIP policy has encouraged the adoption of anti-TIP legislation.

${ }^{40}$ Response 1202.

${ }^{41}$ Responses 1021, 1213, 1274, 1307, 1353, 1486, and 1505.

${ }^{42}$ Responses 1251 and 1255 .

${ }^{43}$ Responses 1099, 1327, 1397, and 1514.

${ }^{44}$ Responses 1287, 1288, 1290, and 1311.

${ }^{45}$ Response 1360.

${ }^{46}$ Responses 1084, 1204, 1251, 1280, 1288, 1336, and 1349.

${ }^{47}$ Responses 1162, 1381, and 1494.
} 
$40 \%$ report that the United States has run public awareness programs in their countries. In several countries, NGOs observe that U.S. embassies hold special press conferences and other events following the release of the annual TIP report and publicly acknowledge any TIP Heroes or other recipients of special U.S. awards. ${ }^{48}$ For example, Ghanaian NGOs explain how the embassy celebrated a local activist who won the U.S. Department of Labor's Iqbal Masih award for the elimination of child labor, while Ukrainian NGOs describe annual human-trafficking awards ceremonies for local anti-TIP activists at the U.S. embassy. In addition to such events, NGOs say that embassies hold town hall meetings, film nights, and other events and discussions with featured speakers and experts and use social media platforms (including embassy Facebook and Twitter accounts) to directly engage with the broader public. ${ }^{49}$ Embassies also often work directly with national and local media, producing public service announcements and partnering with community leaders, religious figures, and prominent television and movie actors as part of public information campaigns. ${ }^{50}$

In addition to promoting awareness, NGOs report that the United States engages directly in many other public-facing anti-TIP activities. Nearly $40 \%$ of respondents indicated that the United States had convened special workshops and conferences focused on TIP issues in the countries where they work. These workshops tend to be structured as one-day training sessions focused on "trying to get everybody to work together." ${ }^{51}$ Embassy officials bring together American federal agencies such as the FBI and the Department of Homeland Security, domestic law-enforcement agencies, local and national government officials, civil society leaders, and all other relevant stake holders to discuss trafficking issues and to formulate policies. Many NGOs applaud these efforts, claiming that they are especially good at bringing government and civil society together and providing space to "express their opinions [and] share their experiences" with policy makers. ${ }^{52}$ Workshops aimed specifically at linking NGO and government policy efforts are seen as especially effective. ${ }^{53}$ NGOs also note that embassies hold specialized workshops aimed at training and increasing awareness and sensitization for specific industries and firms that tend to be more vulnerable and prone to trafficking, including orphanages, military bases, and the construction and transportation sectors. ${ }^{54}$

Not all NGOs feel that these workshops and trainings are sufficient, however. While most claim that the workshops are good, many noted that the embassy "didn't invite as many people" as they would have liked to see, ${ }^{55}$ "discussion time is too [short]," the discussions, decisions, or promised actions. ${ }^{57}$ Some also criticized the embassy for being too insular and limiting participation to only a few prominent NGOs, and several expressed a desire to be invited to future conferences. ${ }^{58}$ In short, though NGOs generally see U.S.-run workshops and conferences as useful venues for promoting anti-TIP policy and advocacy, more could be done. "Why stop there?" asked one respondent. "If this is a country flagged by the US, why stop there? We need to provide more help and training." 59

In addition to sponsoring embassy-led workshops and events, NGOs report that the United States funds NGO-directed initiatives for improving awareness of trafficking and for providing legal and social services for trafficking victims. Nearly $40 \%$ of respondents indicated that the United States had funded anti-TIP activities in their country. Most organizations note that this support is funneled from the State Department through J/TIP, USAID, and other U.S.-backed foundations or local

\footnotetext{
${ }^{48}$ Responses 1037, 1179, 1208, 1274, 1311, 1336, and 1353.

${ }^{49}$ Responses 1011, 1019, 1369, and 1503.

${ }^{50}$ Responses 1019, 1035, 1084, and 1288.

${ }^{51}$ Response 1254.

${ }^{52}$ Response 1104.

${ }^{53}$ Response 1351.

${ }^{54}$ Responses 1072, 1235, 1382, and 1479.

${ }^{55}$ Response 1254.

${ }^{56}$ Response 1457.

${ }^{57}$ Responses 1227 and 1457.

${ }^{58}$ Responses 1372 and 1378.

${ }^{59}$ Response 1254.
} 
Table 4. Summary of Responses Related to Opinions of the United States.

\begin{tabular}{ll}
\hline Question & \multicolumn{1}{c}{ Summary } \\
\hline Q3.19: Overall, how important a role would you say & Most important actor (26.63\%; 139); Somewhat \\
that the United States or its embassy have played & important actor (34.87\%; 182); Not an important \\
in fighting trafficking in your country over the last & actor (13.03\%; 68); Don't know (25.48\%; 133); \\
10-15 years? & $n=522$ \\
$\begin{array}{l}\text { Q3.25: Overall, has the U.S. influence on human } \\
\text { trafficking policy in your country been positive or } \\
\text { negative? }\end{array}$ & Don't know (11.39\%; 36); Mixed (20.25\%; 64); \\
\hline
\end{tabular}

funding agencies and is used to prepare television segments, to produce fliers and other print materials, to direct street dramas, to offer school programs, to organize rallies, and to conduct other awareness-raising activities, including holding local workshops and conferences for the general public. ${ }^{60}$ In conjunction with funding for awareness, NGOs also report substantial U.S. support for service provision. USAID and J/TIP grants have been used to build safe houses, dormitories, treatment centers, and schools for women and underage victims, offering free medical care, psychological counseling, vocational training, and education in addition to providing shelter and safety. ${ }^{61}$ U.S. support has also allowed NGOs and other organizations to launch and maintain hotlines for raising issues with migration, pay for legal assistance, and consultation in trafficking-related crimes and to form formal coalitions of local anti-TIP NGOs to lobby for improved legislation throughout the region. ${ }^{62}$

U.S. financial support, however, appears to vary by organization size. Many respondents noted that U.S. agencies tend to fund large national NGOs while ignoring smaller organizations that work more closely with trafficking victims or with local advocacy. Some noted that the funding process has become too politicized and that "unless there is someone... that influences [the funding decision]... the neediest entities rarely receive [any money]."63 Others observe that countries such as Japan, Germany, and the Netherlands have given more direct and effective funding to these frontline NGOs, and some have said that they "don't even bother applying" anymore. ${ }^{64}$ This variation in funding does not seem to be rooted in geography. About a quarter of NGOs report receiving direct funding from the United States, and the same proportion of NGOs receive funding in Africa, the Americas, Asia and Oceania, and Europe-there is no statistically significant difference across regions.

\section{Views of the importance and positivity of the United States' anti-TIP efforts}

By and large, NGOs have a strikingly positive view of the U.S. efforts, and the majority of NGOs ascribe some importance to the U.S. government's substantial global anti-TIP work (see Table 4). Given the vocal criticisms of the United States, we were surprised that 6 of 10 respondents (61\%) think that the United States is at least a somewhat important actor in the countries where they work, with over a quarter of all NGOs saying that the United States is the most important actor.

This is not simply because NGOs notice U.S. activities-many organizations emphasize the United States' crucial role in their own work. NGOs have found that the TIP report works "in [their] favour" when training volunteers and confronting government officials ${ }^{65}$ and have appreciated embassy involvement in domestic legal cases against traffickers. ${ }^{66}$ In one instance, direct assistance from the embassy helped an NGO and its host country identify and provide support to

\footnotetext{
${ }^{60}$ Responses 1131, 1196, 1251, 1377, and 1475.

${ }^{61}$ Responses 1301, 1307, 1353, and 1404.

${ }^{62}$ Responses 1007, 1072, 1203, 1353, and 1485.

${ }^{63}$ Response 1238.

${ }^{64}$ Responses 1115, 1227, 1378, and 1474.

${ }^{65}$ Responses 1158 and 1325.

${ }^{66}$ Response 1393.
} 
dozens of victims. ${ }^{67}$ Some NGOs go so far as to say that "none of our success would have been possible without the TIP report" and other U.S. support. ${ }^{68}$

Only $13 \%$ of respondents think that the United States is unimportant in their countries' anti-TIP fights because it is absent, because it "doesn't make much difference," 69 or because the U.S. embassy

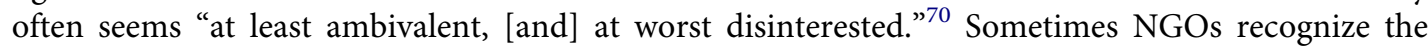
United States for trying but blame local officials for the lack of results. One NGO notes that "the US government has pulled in huge resources for training ... government officials[,] but no concrete results [can] be found," in part because "[those] officials have no interest in such training."71 All in all, NGOs thus overwhelmingly recognize the efforts of the United States.

NGOs clearly recognize the United States as an important actor, but what is their view of the nature of the United States' contributions? After all, it is possible to view an actor as important while still believing that actor to have had a negative effect. Given the criticisms by academics and others, we asked NGOs that considered the United States to be an important or somewhat important anti-TIP actor whether they thought that the United States had played a positive, mixed, or negative role in their countries. Again, the views contrasted starkly with the critical views of more distant observers. A full two thirds agreed that U.S. involvement in the countries in which they work had been positive, while roughly $20 \%$ stated that the U.S. influence had either been mixed or negative. These figures are even greater if one omits the $11 \%$ of respondents who said they did not know. Astonishingly, only two NGOs said that U.S. involvement had been outright negative, so we combine these two categories in our analysis.

What explains these surprisingly supportive views? As the survey made every effort to be neutral and participants had no reason to suspect any connection to the U.S. government, and, since they were furthermore assured full anonymity, participants could express their opinions freely. The views expressed, therefore, are likely sincere. Given that it is often difficult for NGOs to gain attention for their work, many appear to find it helpful to have a powerful actor like the United States shine a light on this problem, engage them in programming and information gathering and hold their governments accountable. Thus, NGOs are probably predisposed to be grateful for any external attention to the issue, and they clearly see the United States as active and, correspondingly, helpful.

Still, the opinions of American importance and positivity do vary. Below, we explore how this variation stems from both country- and organization-level factors that reflect the different experiences and needs of the NGO sector. We explore the associations and relationships between several of these factors below. Note that these associations are merely descriptive and should not be interpreted as causal statements. However, the analysis is instructive as it shows how NGO opinions of the United States vary across subgroups and thus whether they are likely to be artifacts of certain attributes that might bias the assessments.

\section{Country-level explanations}

Figure 5 displays the average level of reported U.S. importance and positivity from NGOs in countries with at least 10 responses. In general, NGOs in most developing countries attribute some importance to the United States, while more developed countries like Canada and the United Kingdom ascribe the least importance, likely indicative of a diminished demand for American anti-TIP assistance in these countries. Opinions of the positivity of U.S. efforts vary by the country where NGOs work, but there appears to be less of a split between non-European and North American countries; for instance, NGOs in both Ghana and Canada were unanimous in regarding U.S. efforts positively. Organizations in countries with the highest average importance-

\footnotetext{
${ }^{67}$ Response 1311.

${ }^{68}$ Response 1509.

${ }^{69}$ Response 1254.

${ }^{70}$ Response 1221.

${ }^{71}$ Response 1298.
} 


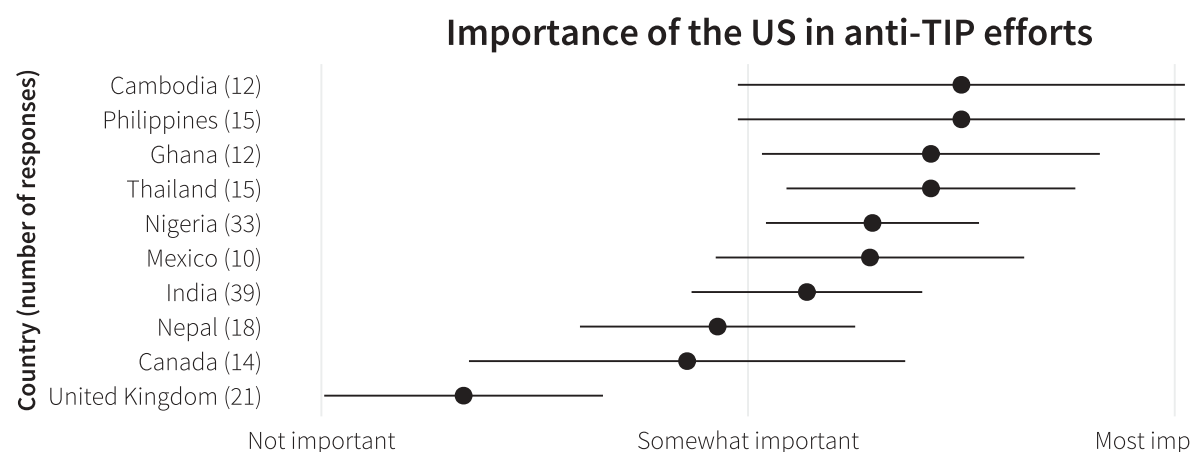

Not important Somewhat important Most important

\section{Positivity of the US in anti-TIP efforts}
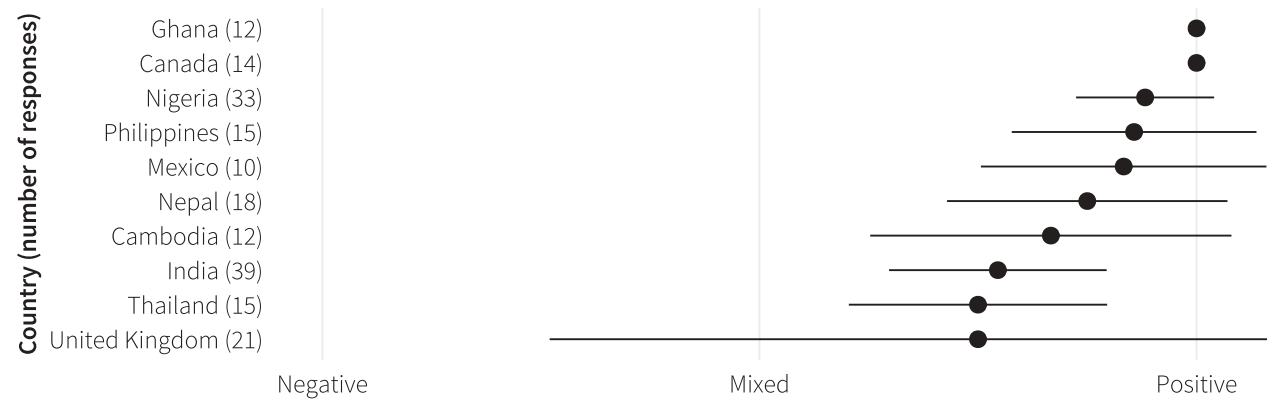

Figure 5. Average importance and positivity of U.S. anti-TIP efforts (error bars indicate $95 \%$ confidence intervals).

Cambodia and Thailand-generally had more varied opinions. These are countries facing enormous human-trafficking problems, and, while help from the United States is appreciated, the severity and scope of the problem complicates the efforts to fight it.

As Figure 6 shows, the association between domestic politics and opinions of the United States holds up when looking at the level of democratic development in the countries NGOs target. On average, NGOs working in countries with worse civil rights and political liberties are significantly more likely to see the United States as the most important anti-TIP actor in that country. Conversely, NGOs in countries with greater democracy tend to view U.S. efforts more positively, while organizations with more mixed opinions work in less democratic countries.

Figure 6 also shows that the severity of trafficking in the countries NGOs target might influence their opinions of the United States. Attitudes towards U.S. importance correlate strongly with the TIP rating of the countries where NGOs work. On average, organizations that think that the United States is the most important anti-TIP actor work in countries with worse TIP ratings, while those that ascribe no importance to the United States work in countries with higher ratings. As with democratic freedom, the relationship between TIP ratings and opinions of the United States' positivity is reversed-organizations that ascribe a positive role to the United States tend to work in countries with better TIP ratings.

Improvements in tier ratings-that is, when a country's most recent rating is better than its initial ranking-do not seem to change NGO views of importance. NGOs in countries that have made greater improvements in TIP policies (as measured by the 3P index), on the other hand, do tend to attribute more importance to the United States, which likely reflects satisfaction with some real progress on the ground. Favorable opinions of U.S. efforts are more clearly (and significantly) associated with improvements in trafficking-NGOs that ascribe a positive role to the U.S. work in countries that have seen the greatest changes in the severity of trafficking, reflected both in the change in tier ratings and in the $3 \mathrm{P}$ policy index. 

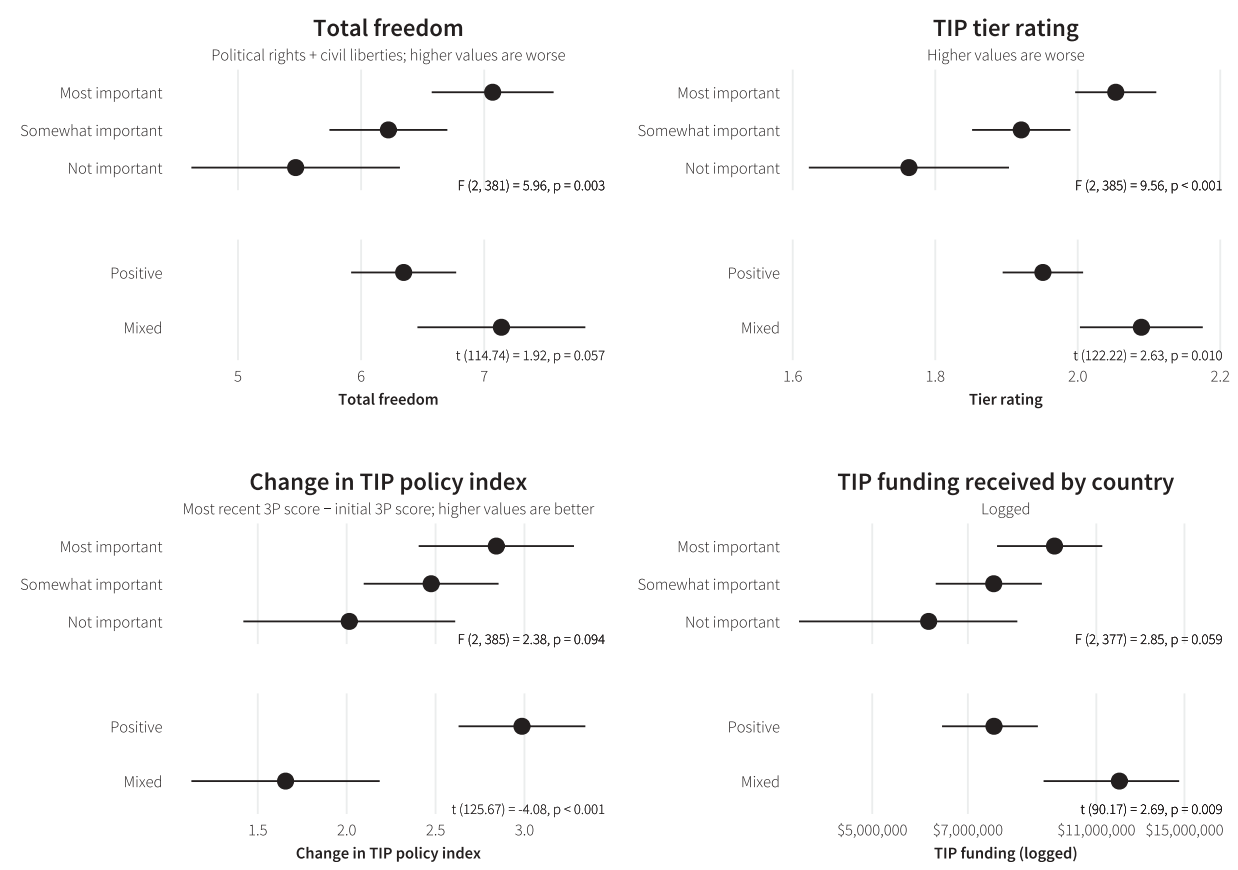

Figure 6. Associations between country-level factors and opinions of U.S. importance and positivity.

Finally, organizations are significantly more likely to think that the United States is an important actor if they work in countries receiving more anti-TIP funding. NGOs that responded that the United States is important work overwhelmingly in countries that receive more financial assistance for TIP efforts. AntiTIP funding is also associated with favorable opinions of U.S. efforts, though inversely from those of importance: Organizations working in countries that receive more U.S. funding are more likely to have mixed opinions of U.S. efforts, likely because the challenges in those countries are greater.

Human trafficking is not restricted by national borders, and government efforts to combat it vary greatly across different regions and subregions (Cho, Dreher, \& Neumayer, 2014). NGO opinions of U.S. importance and positivity also vary by region but in a unique way. Figure 7 shows the average reported importance and positivity from NGOs working in four global regions with Asia and Oceania collapsed (also keeping in mind that the survey omitted U.S.-based NGOs working only in the United States). In general, NGOs think that the United States plays an important role and has a largely positive influence on trafficking policy. However, NGOs working in Asia ascribe more importance to the United States-significantly more so than organizations working in the Americas and Europe. Conversely, though they credit the United States with less importance, NGOs working in Europe are the most likely to think that the United States has played a positive role in their countries. And while NGOs working in Asia tend to rate the United States as the most important, they also report somewhat lower positivity.

This inverse relationship may reflect patterns of trafficking incidence. Most trafficking victims originate from East, South, and Central Asia and arrive in Europe, North America, and the Middle East and North Africa (United Nations Office on Drugs and Crime, 2014). Given that Asia is the front of the trafficking battle, NGOs working there may recognize the importance of U.S. anti-TIP efforts. However, NGOs recognize the magnitude of the problem and realize that the results are sometimes mixed. On the other hand, countries in Europe and the Americas tend to not be origins of trafficking but recipients. NGOs in these regions see the United States as less important, as there are likely fewer frontline NGOs in general, but they feel that the work the in which the United States does engage is quite positive. 

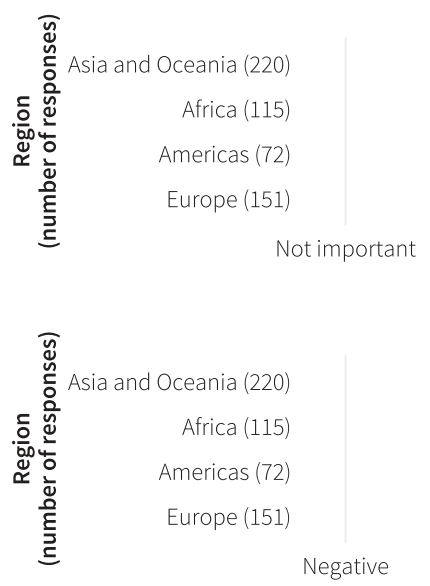

Importance of the US in anti-TIP efforts

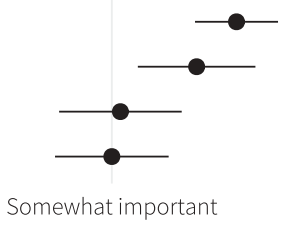

Most important

Positivity of the US in anti-TIP efforts

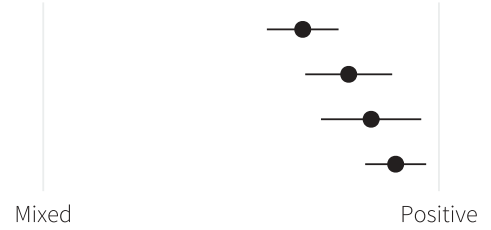

Figure 7. Average importance and positivity of U.S. anti-TIP efforts across regions (error bars indicate $95 \%$ confidence intervals).

\section{Organization-level explanations}

NGO opinions of the United States may be less related to country characteristics than to their individual relationships and experiences with the United States. NGOs that interact more with the United States, that receive more funding from the United States, or that have their headquarters there could be positively biased towards the United States and rate it more favorably. However, as shown in the statistical associations in Figure 8, contact with the United States is not necessarily related to NGO opinions of the country's importance and positivity.
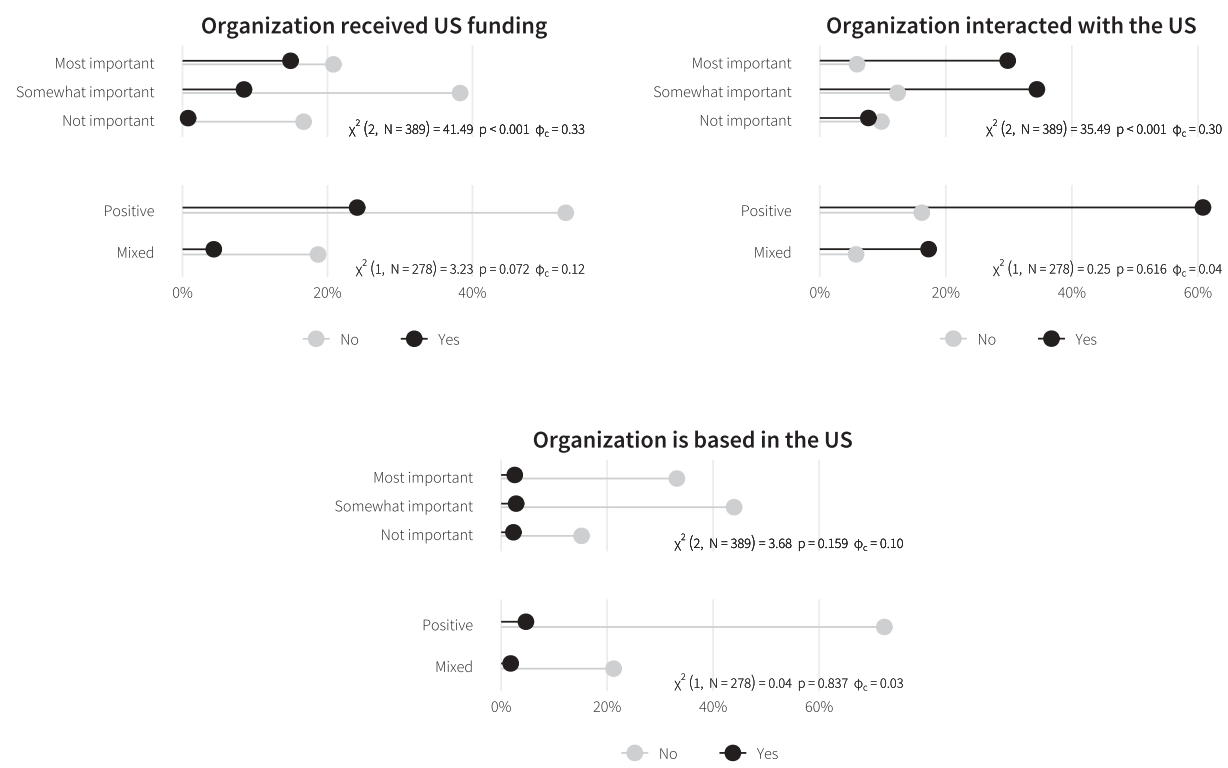

Figure 8. Associations between organization-level factors and opinions of U.S. importance and positivity. 
The majority of NGOs that report receiving funding directly from the United States feel that it is the most important anti-TIP actor. However, only $24 \%$ of responding organizations received funding, so this association does not necessarily mean that the United States is simply buying endorsements from NGOs. Even when removing all U.S.-funded NGOs from the sample, nearly $80 \%$ think that the United States is important-actually more than when those receiving funding are included.

Similar to funding, having any kind of encounter or involvement with the U.S. embassyincluding direct contact, meetings, or other types of cooperation-is associated with higher opinions of U.S. importance. NGOs that reported that the United States was an important actor were more likely to have been involved with the United States. Importantly, however, direct experience with the United States appears to be more strongly associated with opinions than simple connections to the United States-NGOs that are headquartered in the United States are not significantly different from their foreign counterparts in their opinions of American importance.

Much of the literature suggests that NGOs that depend on funding can be co-opted by their donors or sponsors (Baur \& Schmitz, 2012; Bush, 2015; Najam, 2000). This appears not to be the case here, however. While direct NGO experiences with the United States are loosely associated with opinions of the United States' anti-TIP importance, no organizational factors are significantly associated with NGO attitudes of the positivity of American efforts, suggesting that NGOs are not being co-opted by the United States.

\section{Conclusion}

Based on the longstanding and ongoing debate in academic, political, and policy circles about the effectiveness of the United States' 15-year fight against human trafficking, including criticism over the underlying political motivations behind its self-appointment as the global leader against TIP issues, one might expect that NGOs would view the U.S. efforts negatively. Multiple accusations of ineffectiveness might also lead one to believe that U.S. efforts are more talk than action, and that organizations on the ground would therefore either be unfamiliar with these efforts or dismiss them as fluff. Finally, one might also expect that any organization that does support U.S. efforts would have been co-opted and influenced through U.S. funding.

The results are quite to the contrary. NGOs that work in the trenches of anti-TIP advocacy are surprisingly sanguine about American efforts. Our sector-wide survey found that NGOs are by and large quite satisfied with U.S.-led efforts and find them to be effective and powerful allies in NGOs' own anti-trafficking work. NGOs are not unanimous in their praise for the United States, and their opinions are varied and nuanced, but, in the difficult context of addressing an issue as complex as human trafficking, NGOs generally appreciate U.S. assistance and support. We found that they regularly use the TIP report to engage with each other and with their respective governments, and, in general, most organizations feel that U.S. efforts have been effective.

In light of these findings, it might be worthwhile to renew assessments of the U.S. anti-TIP policy. Many of the academic critiques are more than a decade old, and some scholars have noted the U.S. report has come a long way since its early years (Gallagher, 2014a). For instance, early critiques of the American stance on prostitution have been tempered by a 2013 U.S. Supreme Court ruling striking down antiprostitution language that required U.S. aid recipients "to pledge allegiance to the government's policy of eradicating prostitution" as a funding condition (United States Agency for International Development v. Alliance for Open Society International, 2013). Additionally, it would be interesting to assess the views of other actors such as intergovernmental organizations ${ }^{72}$ or local government officials. Following work by Cho

\footnotetext{
${ }^{72}$ One of the authors has conducted interviews of staff at the ILO, the IOM, the United Nations Children's Emergency Fund (UNICEF), and other international governmental organizations (IGOs) and found similarly positive views of U.S. efforts, by and large. However, these interviews were not as systematic as this NGO survey.
} 
et al. (2014), it may also be valuable to explore further regional variation. For instance, a recent survey of government officials found that the TIP report has little influence in the Middle East and North Africa, but unfortunately this conclusion was based on very few responses (Parks, Rice, \& Custer, 2015).

The difficulty of obtaining reliable information raises yet another issue long discussed by scholars. While the survey can assess NGO views of U.S. policies, we still lack dependable data to assess the actual policy outcomes-something for which scholars have long called but that is fraught with tough methodological challenges (Goodey, 2008; Laczko, 2005; Tyldum \& Brunovskis, 2005). Some research uses the actual tier ratings from the U.S. TIP report as a measure of progress, but this is inappropriate given that ratings measure government efforts not the actual outcomes of those reforms. A new measure, the Global Slavery Index, offers hard numbers of human-trafficking incidence, but it is unfortunately flawed (Gallagher, 2014b; Guth, Anderson, Kinnard, \& Tran, 2014).

This article's attention to NGOs in anti-trafficking efforts is rare but is needed. NGOs are the frontline warriors in the fight against human trafficking, yet little research has been done on their functions and effectiveness. The only pan-NGO survey was conducted in 2002 and included fewer than 150 NGOs, although that may have been the extent of the NGO community at the time (Tzvetkova, 2002). A recent study that analyzes the activities of a sizable database of NGOs collected from the Internet is a welcome addition (Limoncelli, 2016). Crucially, however, the survey described in this article is the first to consult NGOs about their activities and opinions. In the future, NGOs may help solve the intractable issues with trafficking-data availability, possibly providing some estimates of trafficking incidence or reporting more actively from the ground.

In addition to insights about the perception of U.S. anti-trafficking efforts, the survey results highlight a relationship between civil society and international diplomacy that has not yet been explored, raising several interesting questions worthy of future research. As seen in the case of American-led anti-TIP advocacy, states can gain diplomatic prominence and influence by championing social issues through an existing network of civil society organizations already involved in those issues. How do states decide which issues to champion, and what role does civil society play in that decision? Did the existence of an active anti-TIP NGO sector influence the United States' decision to become the global leader in trafficking advocacy, or did its vast array of financial and material support for NGOs lead to an expansion of the sector? What determines when a state will successfully harness a global crisis or issue? Is a connection to on-the-ground activists necessary for a state to become a global leader in that issue? Does such a close connection between foreign governments and domestic NGOs affect local perceptions of civil society?

Finally, the survey results provide a word of caution for the future of the United States' anti-TIP advocacy. Linking foreign policy with advocacy is fraught with risk. As noted earlier, the State Department has been under considerable political pressure to rank countries in ways that promote American diplomacy-in 2015 alone, senior J/TIP officials reportedly overruled local embassy tier recommendations in 17 different countries and inflated the tier assignments for 14 countries because of their importance in U.S. foreign policy (Szep \& Spetalnick, 2015). The surprising support and enthusiasm that our survey has revealed underscores the importance of minimizing any outright politicization of the TIP report. Though they have been one of the State Department's staunchest allies, NGOs have begun to question the validity of the TIP report, noting the inherent tension between advocacy and politics and some suggesting that "tier decisions are politically motivated rather than honestly evaluated." ${ }^{33}$ While such views would be likely even in a more neutral reporting environment, the United States might want to consider additional ways to insulate the TIP report from political pressures, which can weaken its diplomatic value and power. It is clear from the survey that the United States has stimulated a powerful global effort against human trafficking. The overwhelming support of NGOs around the world suggests it is worth preserving and improving. 


\section{Funding}

This work is made possible by a grant from the National Science Foundation (award number 1260423) and by generous funding from the Smith Richardson Foundation. All views are our own.

\section{ORCID}

Andrew Heiss (D) http://orcid.org/0000-0002-3948-3914

\section{References}

Baruch, Y., \& Holtom, B. C. (2008). Survey response rate levels and trends in organizational research. Human Relations, 61(8), 1139-1160. doi:10.1177/0018726708094863

Baur, D., \& Schmitz, H. P. (2012). Corporations and NGOs: When accountability leads to co-optation. Journal of Business Ethics, 106(1), 9-21. doi:10.1007/s10551-011-1057-9

Bush, S. S. (2015). The taming of democracy assistance: Why democracy promotion does not confront dictators. Cambridge, UK: Cambridge University Press. doi:10.1017/cbo9781107706934

Büthe, T., \& Mattli, W. (2011). The new global rulers: The privatization of regulation in the world economy. Princeton, NJ: Princeton University Press. doi:10.1515/9781400838790

Chacon, J. (2006). Misery and myopia: Understanding the failures of US efforts to stop human trafficking. Fordham Law Review, 74(6), 2977-3040. Retrieved from http://ir.lawnet.fordham.edu/flr/vol74/iss6/3

Cho, S.-Y. (2015). Evaluating policies against human trafficking worldwide: An overview and review of the 3P index. Journal of Human Trafficking, 1(1), 86-99. doi:10.1080/23322705.2015.1014660

Cho, S.-Y. (2016). 3P Anti-trafficking policy index. Marburg, Germany: Philipps-University of Marburg. Retrieved from http://www.economics-human-trafficking.net/data-and-reports.html

Cho, S.-Y., Dreher, A., \& Neumayer, E. (2014). Determinants of anti-trafficking policies: Evidence from a new index. The Scandinavian Journal of Economics, 116(2), 429-454. doi:10.1111/sjoe.12055

Chuang, J. A. (2006). The United States as global sheriff: Using unilateral sanctions to combat human trafficking. Michigan Journal of International Law, 27(2), 437-494. Retrieved from http://ssrn.com/abstract=990098

Chuang, J. A. (2014). Exploitation creep and the unmaking of human trafficking law. The American Journal of International Law, 108(4), 609-649. doi:10.5305/amerjintelaw.108.4.0609

DeStefano, A. (2007). The war on human trafficking: US policy assessed. New Brunswick, NJ: Rutgers University Press.

Dupuy, K. E., Ron, J., \& Prakash, A. (2014). Stop meddling in my country!: Governments' restrictions on foreign aid to non-governmental organizations (Working Paper). Retrieved from http://ssrn.com/abstract=2529620

Dupuy, K. E., Ron, J., \& Prakash, A. (2015). Who survived?: Ethiopia's regulatory crackdown on foreign-funded NGOs. Review of International Political Economy, 22(2), 419-456. doi:10.1080/09692290.2014.903854

Edwards, P. J., Roberts, I., Clarke, M. J., DiGuiseppi, C., Wentz, R., Kwan, I., \& Pratap, S. (2009). Methods to increase response to postal and electronic questionnaires. Cochrane Database of Systematic Reviews, (3). doi:10.1002/ 14651858.MR000008.pub4

Efrat, A. (2012). Governing guns, preventing plunder: International cooperation against illicit trade. New York, NY: Oxford University Press. doi:10.1093/acprof:oso/9780199760305.001.0001

Foerster, A. (2009). Contested bodies: Sex trafficking NGOs and transnational politics. International Feminist Journal of Politics, 11(2), 151-173. doi:10.1080/14616740902789500

Foot, K. A., Toft, A., \& Cesare, N. (2015). Developments in anti-trafficking efforts: 2008-2011. Journal of Human Trafficking, 1(2), 136-155. doi:10.1080/23322705.2014.980663

Freedom House. (2016). Freedom in the world report. Washington, DC: Author. Retrieved from https://freedomhouse. org/report-types/freedom-world

Gallagher, A. T. (2011). Improving the effectiveness of the international law of human trafficking: A vision for the future of the US Trafficking in Persons Reports. Human Rights Review, 12(3), 381-400. doi:10.1007/s12142-010-0183-6

Gallagher, A. T. (2014a, June 27). The trafficking watchlist may be flawed, but it's the best measure we have. The Guardian. Retrieved from http://www.theguardian.com/global-development/poverty-matters/2014/jun/27/humantrafficking-watchlist-report

Gallagher, A. T. (2014b, November 28). The global slavery index is based on flawed data-Why does no one say so? The Guardian. Retrieved from http://www.theguardian.com/global-development/poverty-matters/2014/nov/28/glo bal-slavery-index-walk-free-human-trafficking-anne-gallagher

Gallagher, A. T. (2015). Two cheers for the trafficking protocol. Anti-Trafficking Review, 4, 14-32. doi:10.14197/ atr.20121542

Gallagher, A. T., \& Chuang, J. A. (2012). The use of indicators to measure government responses to human trafficking. In K. Davis, A. Fisher, B. Kingsbury, \& S. E. Merry (Eds.), Governance by indicators: Global power through 
classification and rankings (pp. 317-343). Oxford, UK: Oxford University Press. doi:10.1093/acprof:oso/ 9780199658244.003 .0013

Garcia, G. (2006, June 28). The State Department Human Trafficking Report: Raw ideology rather than bona fide research. Washington, DC: Council on Hemispheric Affairs. Retrieved from http://www.coha.org/the-state-depart ment-human-trafficking-report-raw-ideology-rather-than-bona-fide-research/

Goodey, J. (2008). Human trafficking: Sketchy data and policy responses. Criminology and Criminal Justice, 8(4), 421442. doi:10.1177/1748895808096471

Government Accountability Office. (2006). Human trafficking: Better data, strategy, and reporting needed to enhance U.S. antitrafficking efforts abroad (No. GAO-06-825). Retrieved from http://www.gao.gov/products/GAO-06-825

Guth, A., Anderson, R., Kinnard, K., \& Tran, H. (2014). Proper methodology and methods of collecting and analyzing slavery data: An examination of the global slavery index. Social Inclusion, 2(4), 14-22. doi:10.17645/si.v2i4.195

Heiss, A. (2016a). Amicable contempt: The strategic balance between dictators and international NGOs, Working paper. Durham, NC: Duke University.

Heiss, A. (2016b). The effect of target-country restrictions and authoritarian politics on international NGO programming, Working paper. Durham, NC: Duke University.

Heiss, A., \& Kelley, J. G. (2016). Data and code for From the Trenches: A global survey of anti-TIP NGOs and their views of U.S. efforts. Durham, NC: Duke University. Retrieved from https://github.com/andrewheiss/From-theTrenches-Anti-TIP-NGOs-and-US.

Horning, A., Thomas, C., Henninger, A. M., \& Marcus, A. (2014). The trafficking in persons report: A game of risk. International Journal of Comparative and Applied Criminal Justice, 38(3), 257-280. doi:10.1080/01924036.2013.861355

Kelley, J. G. (2016). Scorecard diplomacy: Using the power of reputation to influence state behavior. Durham, NC: Duke University.

Kelley, J. G., \& Simmons, B. A. (2015). Politics by number: Indicators as social pressure in international relations. American Journal of Political Science, 59(1), 55-70. doi:10.1111/ajps.12119

Kelly, A. (2015, October 21). Uzbekistan accused of brutal crackdown on activists investigating forced labour. The Guardian. Retrieved from http://www.theguardian.com/global-development/2015/oct/21/uzbekistan-forced-labourcotton-harvest-violent-crackdown-activists

Kerry, J. (2015, July 27). Remarks at the 2015 Trafficking in Persons report ceremony. Retrieved from http://www. state.gov/secretary/remarks/2015/07/245298.htm

Laczko, F. (2005). Data and research on human trafficking. International Migration, 43(1-2), 5-16. doi:10.1111/j.00207985.2005.00309.x

Lerum, K., McCurtis, K., Saunders, P., \& Wahab, S. (2012). Using human rights to hold the US accountable for its anti-sex trafficking agenda: The universal periodic review and new directions for US policy. Anti-Trafficking Review, 1, 80-103. doi:10.14197/atr.201215

Limoncelli, S. (2016). What in the world are anti-trafficking NGOs doing?: Findings from a global study. Journal of Human Trafficking. Forthcoming.

Najam, A. (2000). The four C's of third sector-government relations: Cooperation, confrontation, complementarity, and co-optation. Nonprofit Management and Leadership, 10(4), 375-396. doi:10.1002/nml.10403

Nathan, D. (2005, August 11). Oversexed. The Nation [Online]. Retrieved from http://www.thenation.com/article/oversexed/

National Underground Railroad Freedom Center. (2016). U.S. Department of State trafficking in persons report heroes. Cincinnati, OH: National Underground Railroad Freedom Center. Retrieved from http://tipheroes.org

Office of Inspector General. (2012). Inspection of the Office to Monitor and Combat Trafficking in Persons (No. ISP-I12-37). Washington, DC: U.S. Department of State. Retrieved from https://oig.state.gov/system/files/195185.pdf

Parks, B., Rice, Z., \& Custer, S. (2015). The marketplace of ideas for policy change: Who do developing world leaders listen to and why? Williamsburg, VA: AidData, The College of William; Mary. Retrieved from http://aiddata.org/ marketplace-of-ideas-for-policy-change

Polaris Project (2016). Global modern slavery directory. Washington, DC: Author. Retrieved from http://www.global modernslavery.org

R Development Core Team. (2016). R: A language and environment for statistical computing (Version 3.2.4). Vienna, Austria: The R Foundation for Statistical Computing. Retrieved from https://www.R-project.org.

Rosenberg, M., \& Cochrane, J. (2015, July 28). Key shift on Malaysia before trans-pacific partnership deal. New York Times. Retrieved from http://www.nytimes.com/2015/07/28/world/asia/thailands-low-ranking-in-human-traffick ing-report-could-hamper-trade-deal.html

Siskin, A., Wyler, L. S., \& Seelke, C. R. (2009). Trafficking in persons: U.S. policy and issues for Congress (No. RL34317). Washington, DC: Congressional Research Service. Retrieved from http://www.refworld.org/docid/4a72d21e2.html

Szep, J., \& Spetalnick, M. (2015, August 3). Special report: State Department watered down human trafficking report. Reuters. Retrieved from http://www.reuters.com/article/us-usa-humantrafficking-disputes-specialidUSKCN0Q821Y20150804

Tyldum, G., \& Brunovskis, A. (2005). Describing the unobserved: Methodological challenges in empirical studies on human trafficking. International Migration, 43(1-2), 17-34. doi:10.1111/j.0020-7985.2005.00310.x 
Tzvetkova, M. (2002). NGO responses to trafficking in women. Gender \& Development, 10(1), 60-68. doi:10.1080/ 13552070215893

United Nations Office on Drugs and Crime. (2014). Global report on trafficking in persons (Sales No. E.14.V.10). Vienna, Austria: Author. Retrieved from http://www.unodc.org/documents/data-and-analysis/glotip/GLOTIP_ 2014_full_report.pdf

United States Agency for International Development v. Alliance for Open Society International. (2013). 570 U.S.

United States Government. (2000, October 28). Victims of Trafficking and Violence Protection Act of 2000. Retrieved from https://www.congress.gov/106/plaws/publ386/PLAW-106publ386.pdf

Wickham, H. (2009). ggplot2: Elegant graphics for data analysis. New York, NY: Springer. Retrieved from http:// ggplot2.org/book/. Version 2.1.0.

Wooditch, A. (2011). The efficacy of the Trafficking in Persons report: A review of the evidence. Criminal Justice Policy Review, 22(4), 471-493. doi:10.1177/0887403410386217

Wyler, L. S. (2013). Trafficking in persons: International dimensions and foreign policy issues for Congress (No. R42497). Washington, DC: Congressional Research Service. Retrieved from http://www.refworld.org/docid/5204ebea4.html

Zaloznaya, M., \& Hagan, J. (2012). Fighting human trafficking or instituting authoritarian control. In K. Davis, A. Fisher, B. Kingsbury, \& S. E. Merry (Eds.), Governance by indicators: Global power through classification and rankings (pp. 344-364). Oxford University Press. doi:10.1093/acprof:oso/9780199658244.003.0014

\section{Appendix A: Software}

All figures, tables, and other results can be replicated using code available in an online repository (Heiss \& Kelley, 2016), and with R 3.2.4 (R Development Core Team, 2016) and ggplot 2.1.0 (Wickham, 2009).

\section{Appendix B}

We shared our list of NGOs with the Global Modern Slavery Directory (http://www.globalmo dernslavery.org), which Polaris Project compiled concurrently with our own data collection. Most of the organizations we surveyed are included in their directory. We did not share the contact information of respondents who requested anonymity in the survey, though the Global Modern Slavery Directory may have collected their information independently. We generated our initial list using the following directories and databases:

- Academy for Educational Development. HumanTrafficking.org. Retrieved from http://humantraf ficking.org/

- Directory of Development Organizations. Retrieved from http://www.devdir.org/

- Duke University Libraries. NGO research guide. Retrieved from http://guides.library.duke.edu/ ngo_guide

- ECPAT International. Where we are. Retrieved from http://ecpat.net/where-we-are

- Gale. Associations Unlimited. Retrieved from http://associationsunlimited.com

- Global Alliance Against Traffic in Women. GAATW members. Retrieved from http://www.gaatw. org/\#members

- Kristof, N. D. (2006). Anti-trafficking groups. New York Times: On The Ground Blog. Retrieved from http://kristof.blogs.nytimes.com/2006/01/23/anti-trafficking-groups/

- List of organizations that combat human trafficking. Wikipedia. Retrieved from https://en.wikipe dia.org/w/index.php?title=List_of_organizations_that_combat_human_trafficking\&oldid= 553998390

- Union of International Associations. Yearbook of International Organizations. Retrieved from http://www.uia.org/yearbook

- United Nations Office on Drugs and Crime. Electronic NGO database. Retrieved from http://www. unodc.org/ngo/list.jsp

- United States Department of State. (2001-2015). Trafficking in Persons Report.

- WiserEarth. Retrieved from https://web.archive.org/web/20130701035555/http://wiser.org 